\title{
Lessons to be Learned from the Experience of Electricity Reforms in India
}

\author{
Sharad B. Karmacharya
}

\begin{abstract}
The electricity sectors in India have been undergoing significant reforms since nineties. The initial status of the electricity sector when reform of the industry was initiated was very similar across all states in India. The state electricity boards prior to reform were vertically integrated public utilities, the distribution companies had significant technical and commercial losses and the state utilities were in poor financial health. Most states in India shared similar stories; however, when these states reformed their electricity sector in the nineties, we see differences in the current market structure despite all states having started with similar industry organization. In this paper, we carry out case studies of electricity sector reforms in Orissa, Delhi and Karnataka. These three cases have been selected for their diversity in approaches to electricity reform. What motivated these states to reform? What types of market designs are currently in place and why market designs differed in these states? We analyse these cases and aim to explain the differences in sector performances and extract some lessons in the context of Nepal's electricity sector.
\end{abstract}

Key words: Electricity reforms, case study, Orissa, Delhi, Karnataka, India

\section{Background}

Alectricity reform in developing countries has Elargely been based upon the same 'standard menu' that underlies reforms in developed countries. As a result, reforms in developing countries are implemented more slowly or have even stalled (Wamukonya 2003; Victor and Heller 2007; Bhattacharya 2007; Ramamurti 1999). India embarked on reforming its electricity sector in the mid-nineties beginning with Orissa. This was followed by reforms in Delhi and other states in India. This case study of India provides a unique opportunity as the states within India share a common economic and political framework while each state has had the freedom to manage its utilities within its state borders. This gives us the opportunity to do a comparative analysis of the alternative approaches followed by different states. It helps us to compare why different states had different reform initiatives despite having similar institutional frameworks (political framework, regulatory framework, governance of utilities). Studying these different states also helps us identify which factors contributed to the success or failure of the reform efforts. This study contributes to the comparative analysis of electricity reforms in Orissa, Delhi and Karnataka and to draw valuable lessons for Nepal from their experience.

\section{Recent Developments in the Power Sector Policies of India}

In 1998, the Electricity Regulatory Commissions (ERC) Act was introduced making it obligatory for all states to establish state electricity regulatory commissions (GOI 1998). The Electricity Act 2003 (EA 2003) is the latest step defining the legal framework for the electricity sector. This Act acknowledged electricity trading as a separate activity. Among others, the objectives of this Act are to promote competition in electricity generation, protecting interest of consumers and supply of electricity to all areas, rationalization of electricity tariff, and formation of a regulatory commission in all states (GOI 2003). After EA 2003, there have been some new developments, which are geared towards wholesale competition: an open access regulation was issued by the federal regulatory commission in 2004 requiring all state transmission utilities to provide open network access. This is one of the key requirements for wholesale competition allowing generation companies and distribution companies with open access for energy exchange. A most recent development (since 2008) is the introduction of power exchange for hourly day ahead trading.

\section{Orissa Electricity Sector}

Orissa is a resource rich state with significant coal mines. It has a number of pit-head based coal plants. It exports power to other states, especially to the power hungry western region and southern region during the dry season. Currently, transmission capacity is adequate with little or no congestion; however, as new generation plants are built, the need for new transmission capacity will be critical for export of electricity from Orissa. Orissa is located in the Bay of Bengal region where cyclones are frequent during the monsoon season. In 1999, a cyclone destroyed much of the power lines and equipment. Although, rich in mineral resources, Orissa is among the poorest states in India.

\section{Current Electricity Market Design}

Orissa is the first state in India to reform its electricity market. Part of the motivation comes from internal factors namely the state's failure in financially supporting the state electricity board, which was running at significant losses, and part of it comes from external forces namely the international financial institutions and the international trend of reforming the electricity sector at that time. In 1995, the Orissa State Electricity Board (OSEB) was unbundled to form generation, transmission and distribution companies. The Orissa Electricity Regulatory Body (OERC) was formed and distribution 
companies were privatized. This was a new institutional framework, and it was a new territory for the newly formed regulatory body. Even though the intention of reform was to improve sector performance and increase investment, Orissa had a bitter experience especially in the distribution sector where the private parties who bought the assets made very little investments and the losses are still high.

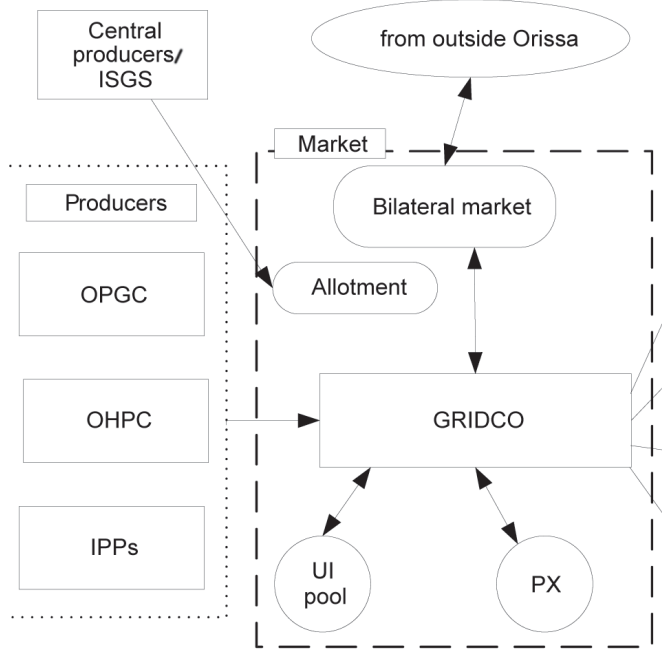

Figure 1. Current Electricity Market in Orissa.

Orissa has a single buyer model with GridCO as the single buyer. GridCo also takes part in the national market by buying or selling through bilateral contracts. It also trades in the Indian Energy Exchange (IEX). It buys energy from state generation companies under longterm power purchase agreements/contracts. It sells to distribution companies also on long-term contracts. Any excess energy is sold by GridCo in the national market in the power exchange or to other states through bilateral contracts. WESCO, NESCO and SouthCo are distribution companies owned by Reliance Power. Central Electricity Supply Utility (CESU) (originally Central Electricity Supply Company (CESCO)) was owned by AES, an American company, but it left the market as it found it difficult to carry out business in Orissa. CESCO was then owned and managed by a management committee from the regulatory commission. GridCo buys power from all of its state generators and also buys power from other states. After the Electricity Act 2003, GridCo has been separated from Transco to unbundle the transmission activity from trading. In Orissa, distribution companies have been privatized. GridCo and Transco both are owned by the Orissa state government. OHPC, the hydropower generation company is also owned by the state of Orissa while OPGC a thermal generation company is owned partly by the Orissa state government and partly by AES.

\section{Post Reform Events}

After privatization, the distribution companies started their business with significant liabilities and there was no support from the state government during the transition phase. It became difficult for them to borrow with significant debts in their balance sheet. This left the distribution companies with little motivation to invest in improving the sector. As a result, we have not seen investments as in the case of Delhi where, unlike Orissa, the distribution companies invested heavily in improving the system performance.

One of the earliest blows to the Orissa electricity reform was the departure of AES, which had bought the Central Electricity Supply Company, one of the distribution companies with significant distribution losses. AES had reluctantly bought CESCO after the state government could not find any buyer for this distribution company during the privatization process (Ramanathan and Hasan 2003). With significant liabilities from the beginning of buying the assets and lack of support from the government during the transition phase, AES decided to pull off from the distribution business.

CESCO, which was bought by AES, was taken over by the regulator, and currently it is being managed by a group of members from the state regulator. The name of the company has now been changed to CESU as it is no more a private company. The regulator is still looking for an investor to sell this company.

After the EA 2003, the market situation changed with more opportunities to trade electricity through open access. GridCo was formed to separate the business activity from transmission activity as per the EA 2003. Although, during restructuring the old state utility, the plan was to have a single buyer as a temporary phase before wholesale competition; however, GridCo still operates as a single buyer in Orissa.

GridCo, the single buyer and bulk supplier, which inherited the losses of OSEB during reform, is in a much better position than the distribution companies. With opportunities of trading electricity in the bilateral market and power exchanges, GridCo has a more secure financial position. It uses its net profits to keep the bulk supply price low and to write off its past debts. However, with a negative balance sheet, the distribution companies do not have enough incentives to invest in improving the distribution sector. As a result, there has been limited investment in the distribution sector, and the performance of the sector has not improved much.

\section{Delhi Electricity Sector}

Delhi is different from other states in India. It is a small state with a large urban area and very little rural population. Its population has boomed from 1.74 million in 1951 to 4 million in 1971 to about 14 million 
in 2001. This means a significant demand for residential consumption. Another typical characteristic of Delhi is its sharp variation of peak and off peak load, both daily and seasonal. Delhi has limited local generation but the combination of its own generation with allocated capacity from the central generation is sufficient for the base load. However, for the peak load, it needs to import from neighbouring states through bilateral contracts. It has negligible agricultural load, which gives the distribution companies in Delhi an advantage compared to other states as this results in less subsidies for agriculture consumers thereby improving the cost recovery of distribution companies.

\section{Current Electricity Market Design}

Delhi is the second state in India to reform its electricity sector. Part of its motivation came from internal pressure, as the state government had to bear high power subsidies to the Delhi Vidyut Board (DVB) and partly due to poor performance, which resulted in a number of street protests in Delhi pressurizing the policy makers to think about reform. Part of the motivation also comes from the external pressures from international lending institutions. As in the case of Orissa, Delhi also unbundled its vertically integrated electricity board, set up a regulatory body and privatized its distribution companies. Looking superficially, both states seem to have gone through the same process of reform; however, the difference between Orissa and Delhi reforms lies in the details of reforming the electricity sector. Learning from the experience of Orissa, the Delhi state government devised an incentive mechanism to reform the ailing industry. Privatization of distribution companies was not based on the highest bidder of assets like in Orissa but was based on the commitment to reduce distribution losses.

Delhi had a single buyer during its transition period but in 2007, the transmission company stopped acting as a single buyer and wholesale competition became active in Delhi. The distribution companies buy power directly from the generators, be it from Delhi or from other state. The electricity market in Delhi is shown in Figure 2.
Currently Delhi has a wholesale competition model where the distribution companies can buy directly from any generation companies. During the reform process of DVB, the transmission company, Delhi Transmission Company (DTC), acted as a single buyer during the transition phase. In 2007, DTC transferred all power purchase agreements to distribution companies, relieving itself from any commercial activities.

The distribution companies in Delhi have been privatized except for a small municipal and army related distribution zones. NDPL was bought by Tata Power and BYPL and BRPL was bought by Reliance Power. Both these companies are domestic power companies. The transmission company is under the state government of Delhi. In generation, there are two large state generation companies, IPGCL and Pragati Power, which are corporatized public companies.

In Delhi, distribution companies started their business with fresh balance sheets without any liabilities from the predecessor. While in Orissa, the distribution companies that bought the utilities also got liabilities of the previous owner so that when they started their business, they had a negative balance sheet. In addition, state support was given to distribution companies in Delhi during the transition phase on condition that they would reduce distribution losses.

\section{Post Reform}

With support from the state government during the transition phase and incentive from the regulator to improve performance, the distribution companies invested heavily on improving the sector. The distribution losses have been reduced, thanks to investments in upgrading old assets and control of theft.

With effective theft control and metering, customers have become aware about energy usage. Earlier, there used to be misuse of energy as well as abuse of electricity by stealing. Now, with effective billing, use of technology to prevent stealing and good theft control, customer behaviour has changed from energy wastage to energy saving.

The Delhi experience shows that regulation based on

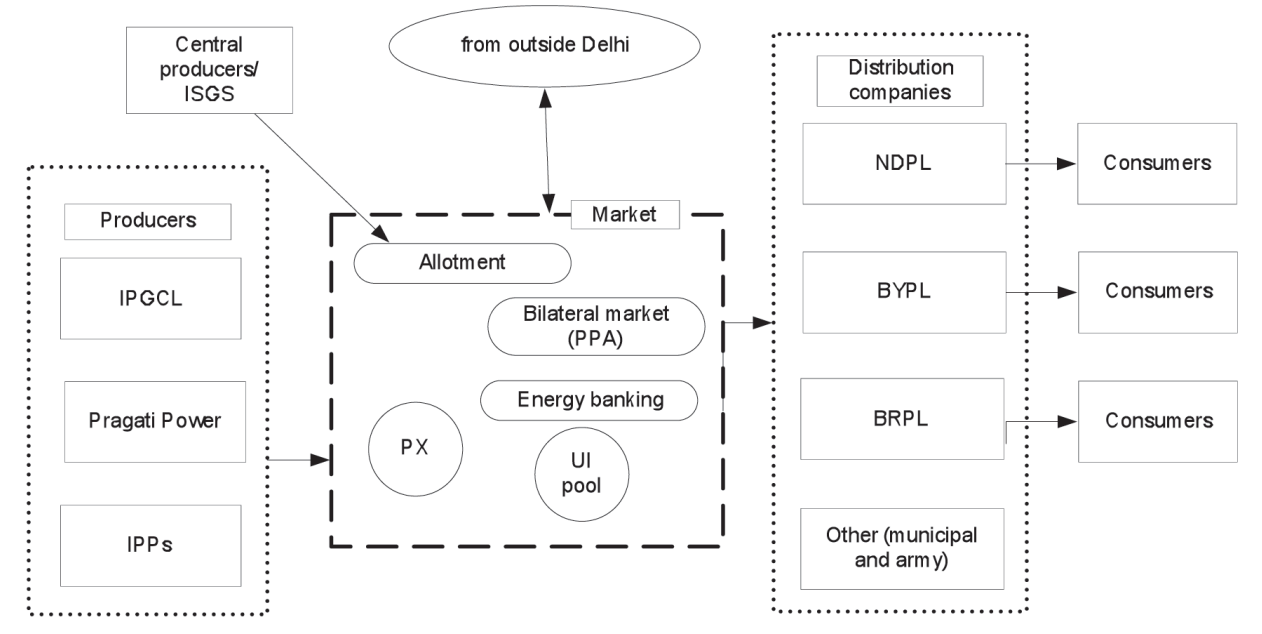
incentives for improving the efficiency is working with significant reduction in losses in the distribution sector. This mechanism has also resulted in investment by private parties in improving the distribution sector, updating the instruments and introducing Information Technology (IT) to manage the distribution sector.

Figure 2. Current Electricity Market in Delhi. 


\section{Karnataka Electricity Sector}

In Karnataka, electricity availability depends on the monsoon and hydrological situation. A recent drought in Karnataka aggravated electricity shortage in the state. The state government issued an order to suspend all open access transactions citing the danger of social disorder due to electricity crisis. Karnataka does not have coal reserves, so any coal based thermal plant has to transport coal from other states, which adds to the cost of production. This discourages new entrants to invest in coal power plants in Karnataka. In addition, there is no gas infrastructure in the state, which acts as a barrier for investors interested in gas power plants. Karnataka is one of the rich states in India and also a state with a growing software industry. Dry seasons have always been a period of electricity shortage and distribution companies often have to buy energy through short term trading at very high prices.

There have been a number of protests from environmental activists against thermal power plants in Karnataka. Apart from some cases, a number of these protests are considered

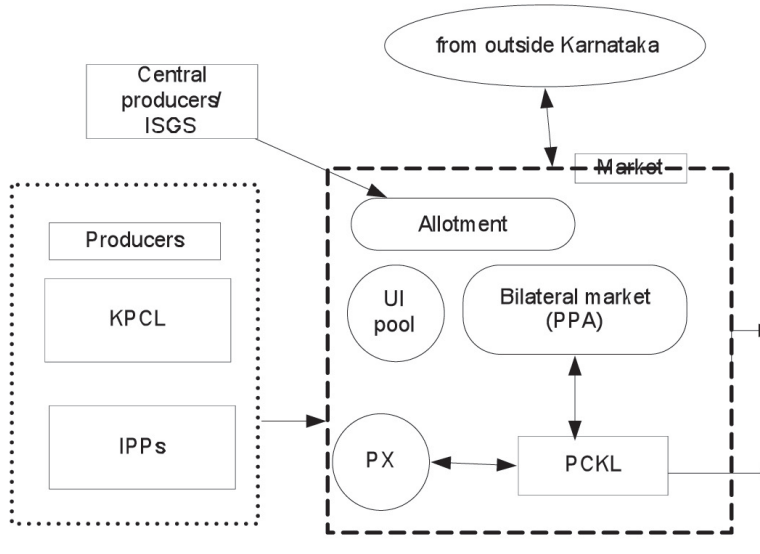

Figure 3. Electricity Market in Karnataka. necessary resources and expertise in procuring energy. Therefore, to reduce transaction costs, a special purpose vehicle called PCKL was set up. PCKL procures power on behalf of distribution companies. It is not a single buyer model as PCKL does not buy power and sell to distribution companies. It is also not a clean wholesale competition where distribution companies freely buy power from generation companies as they use PCKL to procure power through competitive bidding or through bilateral contracts.

In the nineties, the Karnataka Electricity Board (KEB) was a single buyer with integrated transmission and distribution assets and some generation assets. Later in 1999, KEB was unbundled to form a generation company to be politically motivated. This has also been one of the deterrents for investment in power generation. Water disputes with neighbouring states have also been a barrier in investing in hydro plants.

Unlike Delhi and Orissa, there is a large portion of agriculture consumers in Karnataka who receive subsidized electricity. In the nineties, the state government subsidized electricity to farmers, which was more of a political move than an economic strategy. These consumers are considered as vote banks, which means that there is a lack of political will to rationalize the electricity price for agriculture consumers. Subsidy to agriculture and residential consumers means that there is added financial burden on the state government to pay the distribution companies for their unrecovered revenue as subsidy. However, there are concerns that delay in payment by states is adding costs to the distribution companies.

\section{Current Electricity Market Design}

Karnataka has a hybrid design: it is a mix of wholesale competition and single buyer model. After the EA 2003, the transmission company, which was acting as a single buyer, handed all its previous contracts to the distribution companies and distanced itself from commercial activities. In Karnataka, all the distribution companies are state owned and not all of them have the
(VVNL) and a network company KPTCL (transmission and distribution). The network company KPTCL acted as a single buyer. In 2002, KPTCL was broken into a transmission company and four distribution companies. However, until 2005, KPTCL retained its single buyer role and sold energy to distribution companies. In 2005, KPTCL handed over the trading business to the distribution companies as per the EA 2003, which prohibited transmission companies from taking part in the trading activity. In Karnataka, although there is no a single buyer like in Orissa, the distribution companies have come together to form a special purpose vehicle which procures power on behalf of these distribution companies. So Karnataka has neither a single buyer model nor a clean wholesale competition, but a hybrid model which has mixed features of these two models.

KPTCL, the transmission company is under the ownership of the government of Karnataka. All the five distribution companies are also under the state government. A large portion of generation is provided by the state generation company KPCL, which is complemented by some IPPs that are private companies.

In recent years, with a growing economy and increased support from the central government, there has been less pressure on state governments to privatize the distribution sector. Central government programs like RGGVY (for rural electrification) and APDRP (for 
improving the distribution sector) have made state distribution companies financially better off than 15 years ago when Orissa reformed its electricity sector and pursued privatization.

\section{Post Reform}

In 2009, Karnataka had a dry season with very little monsoon rain. This led the state government to suspend the open access to generation companies selling their electricity out of the state. This has increased some concerns among investors on the political commitment during crisis periods.

The state government of Karnataka used section 11 of the EA 2003 to suspend all short-term open access contracts and asked IPPs to sell to the state grid at a certain specified rate, which the state government claims to be higher than the cost of energy for these IPPs. GMR (one of the IPPs) submitted a petition to the High Court of Karnataka to stay the government order (GO). The HC has rejected the stay on GO and directed the concerned Karnataka Electricity Regulatory Commission (KERC) to settle the electricity tariff. This incident brings to light the difficulty of introducing competitive market mechanisms in a supply-constrained zone. Both parties, the concerned IPP as well as the state government have a valid standpoint: the IPP, which is not bound to any agreement with the state, is free to sell electricity to any buyer through open access as stated in the EA 2003; whereas, the state government could restrict open access using the same Act in response to the acute electricity crisis citing it as a state of social emergency. Such incidents of government intervention, which in the short run may be socially justifiable, may in the long run deter private parties from investing in new power plants. With inadequate generation investments in the thermal sector and increasing demand, the state has to buy power from the national market at very high prices.

\section{Comparative Analysis \\ What motivated these reforms?}

In the early nineties prior to reform, in all these states, the state utilities were in a dire financial position. This was because of poor cost recovery due to distribution losses and inadequate retail tariff to cover the cost of supply. A significant portion of the state budget was going to electricity subsidies. The trigger for reform came when India suffered a balance of payment crisis in 1990. After this economic crisis, the federal government began enforcing strict budgetary constraints on state governments. This meant fewer subsidies to state electricity boards, which resulted in limited investment in generation addition and gird maintenance. The state utilities were not able to provide reliable supply of electricity. The second triggering factor was the international trend of reforming the electricity sector. During the same time, encouraged by the success of England and Wales and Argentina in implementing competitive electricity markets with unbundled private parties, international lending institutions were promoting restructuring with privatization as a means to achieve an efficiently managed electricity sector. With a lack of financing options and international pressure, Orissa became the first to reform its power industry. A standard way of reforming was implemented in Orissa where the state utility was unbundled, an independent regulator was established and distribution companies were privatized. After electricity reforms in Orissa, the federal government, in a move to commence electricity sector reform all over India, introduced a regulatory Act in 1998 making it an obligatory for all states to establish an independent regulator. Delhi electricity reform was also motivated by a lack of state finance. In addition to external pressure, there was also an internal pressure from the public to change the management of the power sector, as there were a number of street demonstrations against the poor quality of electricity supply in Delhi. After Orissa and Delhi, the federal government introduced a new EA in 2003 to restructure the power sector all over India in a similar fashion by making it compulsory to unbundle the vertically integrated public utility and by introducing wholesale competition. In Karnataka, the state utility acted as a single buyer, and after this EA, the transmission business was separated from a trading business in 2005, and open access to transmission lines was allowed.

In general, the electricity sector in India has gone through four different industry organizations (see Figure 4). These industry organizations had different motivations and were triggered by different events. During British rule, the electricity industry was motivated mostly by monopoly profits and electricity supply was concentrated in the cities for princes and maharajas. The independence of India in 1947 changed this industry organization. Electricity, being a basic need for better living and an important requirement for industrialization, was considered as the responsibility of the state government. The governments that followed the independence were influenced by the state activism of the USSR and implemented centralized policies to develop infrastructure. This resulted in the vertically integrated State Electricity Boards (SEBs). After droughts and famine in sixties, agriculture policies were highly prioritized. For the electricity sector, this meant an increase in the use of irrigation pumps while tariffs were subsidized. The economic crisis of 1990 triggered another phase of reform with the introduction of private power producers and unbundling of SEBs. Orissa and Delhi reformed their power industry in this phase with privatization of distribution companies. In 2003, the EA by the federal government triggered another phase of reform with the unbundling of utilities and open access in most of the states in India. Since the end of the nineties, the economy has been growing rapidly which meant increased income for distribution companies as well. This increased income plus federal government fund for reform, which meant that there was little pressure on 
utilities to privatize. As a result, none of the states has privatized their utilities after Orissa and Delhi.

\section{What led to differences between reforms?}

Despite having similar organizational setup before reform, the electricity market at present after reform, looks different in Orissa, Delhi and Karnataka. This has to do with exogenous factors, past lessons and the timing of reforms. The Orissa reform began in 1995, to GridCo every year. GridCo has inherited a significant debt from its original utility and being a public utility means that there is a political pressure to keep the prices low. GridCo has been using its profits partly to keep the bulk supply price low and partly to write off its past debts. The regulator has been approving Annual Revenue Requirement (ARR) of GridCo with deficits allowing less revenue from the bulk supply price while expecting it to bridge this revenue gap through UI and trading. With

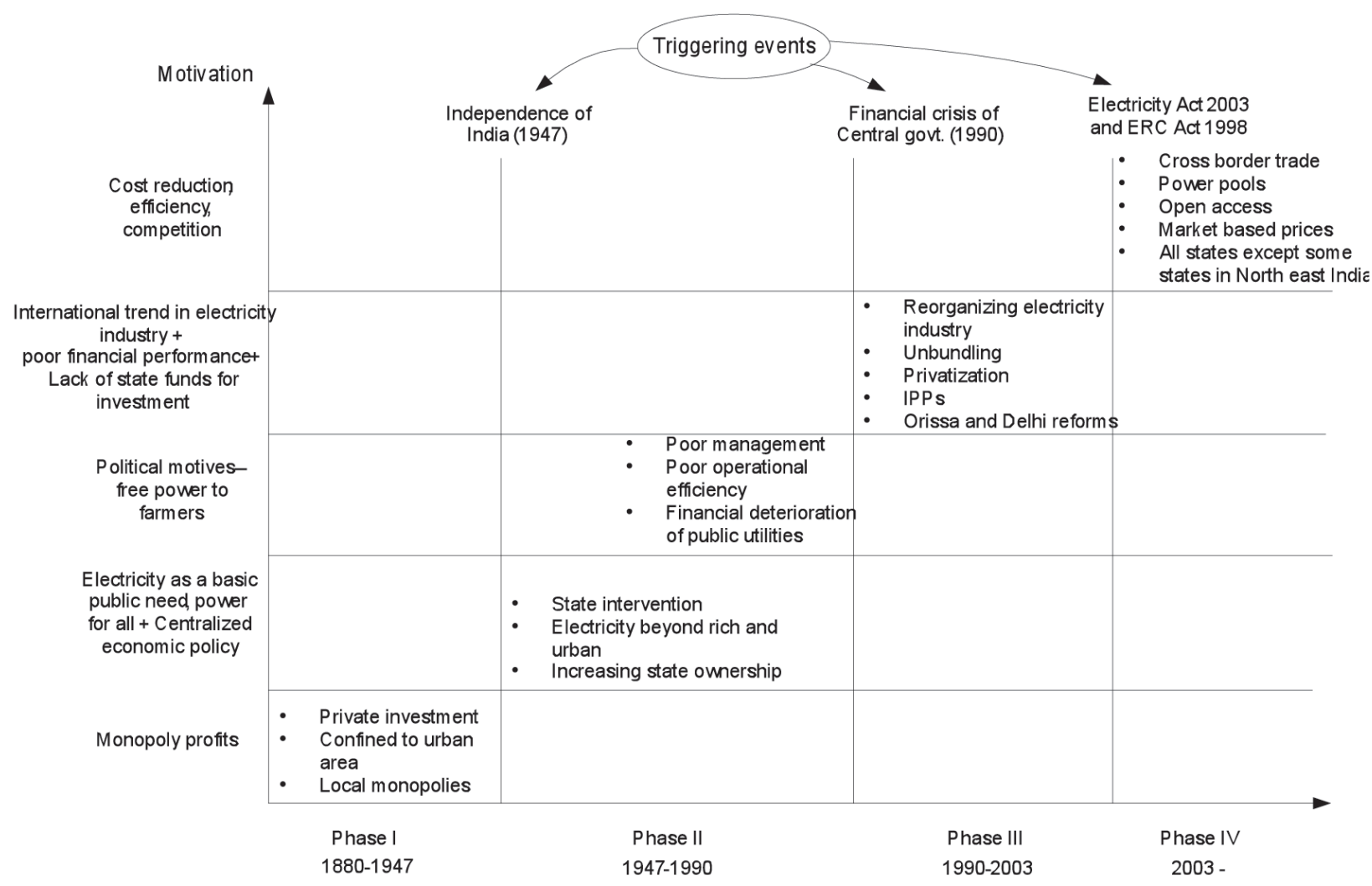

Figure 4. Change in Motivation towards Industry Organization in Power Sector in India.

with a motivation to remove the vertically integrated public utility and introduce wholesale competition with privatized, utilities regulated by an independent regulator. The public utility was unbundled; distribution companies were privatized, and an independent regulator established. When the utility was unbundled, the debts of the original public utility were also divided and shared among the unbundled utilities, which meant that the new utilities started with liabilities in their balance sheets. After the EA 2003, the concept of trading electricity was introduced. In addition, there was a possibility of increasing revenue by assisting to maintain system frequency through unscheduled interchange (UI). Orissa is a resource rich state and there are a number of power projects initiated by the central generation companies. Orissa receives a certain share of this generation as its allotted share. GridCo, which is a single buyer, can sell any excess electricity through UI or through bilateral contracts to other states. The earnings from electricity trading and UI charges have meant increasing net profits
GridCo making a profit and keeping the prices low, the government is unlikely to abandon the single buyer model in Orissa for some time to come.

The experience of privatization in Orissa became a learning point for regulators in Delhi. Instead of selling the assets to the highest bidder, the regulator in Delhi devised an incentive mechanism to privatize its distribution assets. Bids were selected based on the commitment of the private parties to reduce distribution losses. In addition, unlike Orissa, unbundled utilities started with a clean balance sheet and the utilities were given subsidy during the transition phase. This meant that the distribution companies of Delhi were in a better financial position than Orissa. As in Orissa, the transmission operator in Delhi acted as a single buyer during the transition phase, after which, the single buyer model was abandoned and wholesale competition introduced.

Karnataka and other states in India carried out reform after Orissa and Delhi. Major reform initiatives were motivated by federal government regulations. The 
Electricity Regulatory Act of 1998 and Electricity Act 2003 formed the basic legal framework on which reforms were carried out. The Act requires the unbundling of the existing vertically integrated utility and separating the transmission activity from trading activity. In Karnataka, there is no single buyer. In principle, the distribution companies can buy directly from generation companies.

\begin{tabular}{|l|l|r|r|r|r|}
\hline State/UT & \multicolumn{1}{|c|}{ Power Utilities } & $2003-04$ & $2004-05$ & $2005-06$ & $2006-07$ \\
\hline \multirow{5}{*}{ Delhi } & BSES Rajdhani Power Ltd. & 45.73 & 41.97 & 41.25 & 32.93 \\
\cline { 2 - 6 } & BSES Yamuna Power Ltd & 55.54 & 51.70 & 48.58 & 43.25 \\
\cline { 2 - 6 } & North Delhi Power Ltd. & 48.16 & 35.90 & 28.01 & 28.33 \\
\hline \multirow{3}{*}{ Karnataka } & BESCOM, Bangalore & 28.91 & 27.62 & 35.75 & 31.36 \\
\cline { 2 - 6 } & MESCOM, Mangalore & 25.82 & 26.63 & 20.80 & 12.65 \\
\cline { 2 - 6 } & HESCOM, Hubli & 31.66 & 41.64 & 40.38 & 33.84 \\
\cline { 2 - 6 } & GESCOM, Gulbarga & 43.86 & 42.99 & 52.73 & 46.58 \\
\cline { 2 - 6 } & CESCOM, Chamundi & - & - & 46.03 & 40.58 \\
\hline \multirow{5}{*}{ Orissa } & SESCO, Berhampur & 38.22 & 35.65 & 45.48 & 42.17 \\
\cline { 2 - 6 } & NESCO, Balasore & 45.06 & 39.51 & 41.31 & 32.52 \\
\cline { 2 - 6 } & CESCO, Bhubaneswar & 49.96 & 55.82 & 42.54 & 46.96 \\
\cline { 2 - 6 } & WESCO, Bhubaneswar & 38.33 & 35.88 & 33.95 & 36.93 \\
\hline
\end{tabular}

Table 1. AT\&C Losses in Delhi, Karnataka and Orissa (CCEA 2008).

However, not all distribution companies have the administrative capacity to procure power on their own. Therefore, a special purpose vehicle (PCKL) was created. PCKL buys power on behalf of the distribution companies. This is a hybrid of wholesale competition and single buyer. It reduces transaction cost in power procurement activity and increases the negotiation power of distribution companies. Thus, one of the reasons for this hybrid design is due to institutional limitations in carrying out effective wholesale competition.

The Aggregate Technical and Commercial Losses (AT\&C) of state power utilities nationwide is around $35 \%$, which has made these utilities insolvent and unable to invest in their capacity addition programs. In 2003, a federal government funded program called APDRP (Accelerated Power Development and Restructuring Program) was launched in order to bring down these losses to $15 \%$. After five years, the result has not been adequate to call it a success. Table 1 shows the AT\&Closses of Delhi, Karnataka and Orissa for four consecutive years from 2003 to 2007. In Delhi, the distribution sector has shown a remarkable reduction in losses while in Orissa losses are still high. There have not been many changes in the losses in Karnataka except in Mangalore where the losses have continuously reduced from previous years.

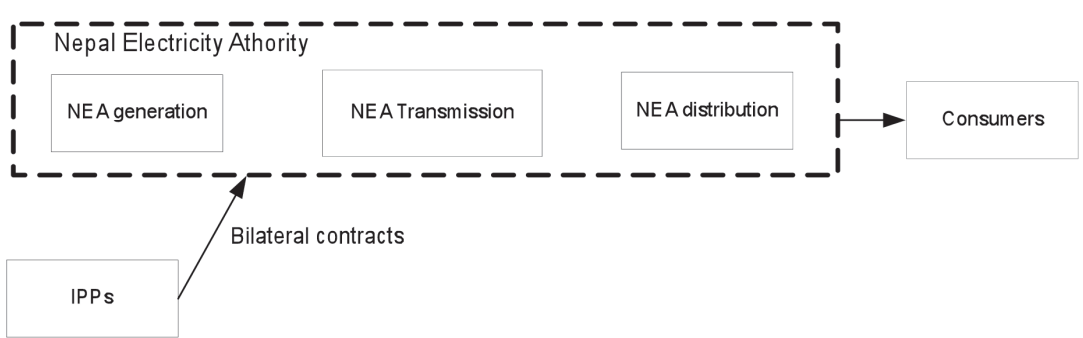

Figure 5. Current Electricity Market Structure in Nepal.

\section{Lessons for Nepal}

The electricity market structure in Nepal the is in a primitive state with the Nepal Electricity Authority (NEA) as vertically integrated utility buying electricity from all IPPs. It has the sole responsibility to sell electricity to all consumers connected to the grid. Private participation is in the generation business alone in the form of IPPs while transmission, distribution and retail business are fully under the jurisdiction of the public utility. There is no provision of an independent sector regulator. The bill to establish an electricity regulatory board is pending since 2007. There are concerns of political interference in the management of NEA. The utility has not been able to maintain financial autonomy from the government; as a result, decisions regarding electricity tariff revision become politically sensitive. Even after the recent increment of electricity tariff (which took place after 11 years from its last revision), the utility's financial position is weak with significant debt overhang. A simple electricity market structure is shown in figure 5 .

The electricity sector in Nepal is in a desperate need of reforms. However, the types of reforms need to suit the conditions in Nepal. A big bang reform, going from a vertically integrated utility to an unbundled privatized utility, would not be suitable due to lack of adequate institutional support and lack of adequate knowledge among stakeholders about the workings of such a system. Rather, Nepal needs incremental reforms to improve the service quality of electricity and to create a favourable environment for investment in new generation.

If Nepal decides to embark on electricity reforms, there are a few things that we can learn from the experience of our neighbours to prepare ourselves before undertaking reforms. Among them, some are discussed in brief below:

- Capacity building of an independent regulatory board

- Proper energy accounting

- Financial unbundling of NEA

The Act meant to establishment an electricity regulatory board has been sent to the parliament. This shows the intent of the government to establish a sector regulator. However, establishing a regulatory board alone does not ensure effective regulation of the industry as seen in the case of Orissa. The regulatory board must have adequate resources and sufficient legal jurisdiction to carry out its job of regulating the industry in an independent manner. Government involvement in the decision making process nullifies 
the establishment of a regulatory board. Hence, the proposed Act on the regulatory body must ensure, the autonomy of the regulator and should have provisions to make the regulatory body resourceful in regulating the industry.

In addition to having adequate preparation before establishing a regulator, the energy accounting in the grid must be accurate enough to assist effective policy implementation. Which group of consumers consumes how much energy? How much energy is consumed whose revenue could not be received due to poor metering, theft and non-payment? What amount of energy is lost due to technical reasons? Accuracy of these figures helps to maintain proper accountability among consumers and network operators. As a result, it becomes easier for the regulator to implement incentive based regulation to reduce the technical and commercial losses which have become a major issue in the financial sustainability of the utility.

Finally, the financial management of the public utility needs to be separated from one another to make losses more transparent. This helps to allocate valuable resources efficiently in improving the service quality of electricity delivery.

\section{Conclusion}

The motivation for power sector reform in India has come from both internal and external factors. Among the internal factors, lack of state finance to invest in new projects has been a key driver to change the industry organization; whereas, the energy policies of international lending organizations during the early nineties are external factors that motivated power sector reforms in India. Past policies have also affected the Indian electricity sector especially when one looks at the agriculture policy of the 196os. Subsidizing agriculture and domestic consumers, which is politically motivated, has affected the financial position of state electricity utilities. Regarding the reform approach, even though the intention of reform was to improve the sector performance and increase investment there has been little success. Orissa had a bitter experience; especially in the distribution sector, where, private parties who bought the assets made very little investments, and the distribution losses are still significant. Learning from the experience of Orissa, the Delhi state government devised a mechanism to reform the ailing industry. Among others, financial support to the privatized distribution companies during the transition phase, and use of incentive-based regulation to improve the performance of the sector hves reduced distribution losses. In Orissa, although reform was initiated to implement the standard model with wholesale competition and privatization, the single buyer model seems like a stable market design. With the possibility to trade electricity, the single buyer in Orissa can today sell extra energy to other states. With its profit, the single buyer has also been able to keep the bulk supply tariff below cost. This makes removing the single buyer model and introducing wholesale competition unlikely in the near future. In case of Karnataka, there is a hybrid model; not all distribution companies in Karnataka have adequate institutional capacity and administrative experience to participate effectively in a wholesale market. Thus, the original state utility, which used to be the single buyer, has created an entity to procure power for all distribution companies. Recent developments show that the economy of India is growing at a fast rate and the federal government is sponsoring the distribution companies for performance improvement. This means that there is increased income for the distribution companies, therefore, there is less pressure on the distribution companies to privatize their assets. All these experiences show that electricity reform in India has been influenced by historical events like subsidy policies; it is affected by physical factors like type and availability of resources; it is also motivated by economic factors like high growth rate; and more importantly, it is affected by institutional capacity and regulatory experience in administering the electricity market. Regarding electricity reforms in Nepal, the key points to focus on prior to under taking electricity sector reforms are ensuring capacity building of the sector regulator, maintaining proper energy accounting and restrenghening the NEA financial management to ensure financial sustainability.

Sharad B. Karmacharya, is a PhD candidate of the Faculty of Technology, Policy and Management, Delft University of Technology.

Corresponding address: Sharad.karmacharya@gmail. com

\section{References}

CEA, 2008, Central Electricity Authority of India, Annual Report 2007/2008

http://www.cea.nic.in/about_us/Annual\%20 Report/2007-08/annual_report_07_o8.pdf.

GOI, 2003, Electricity Act of India.

GOI, 2008, Electricity Regulatory Commission Act of India.

Ramamurti, R., 1999, Why Haven't Developing Countries Privatized Deeper and Faster? World Development, 27, 137-155.

Ramanathan, K. and Hasan, S., 2003, Privatization of electricity distribution, The Orissa experience, New Delhi, TERI Press, The Energy and Resources Institute.

Victor, D. G. and Heller, T. C., 2007, The Political Economy of Power Sector Reform - The Experiences of Five Major Developing Countries, Cambridge University Press.

Wamukonya, N. (2003) Power sector reform in developing countries: mismatched agendas. Energy Policy, 31, 1273-1289. 